\title{
CROSS-CULTURAL EQUIVALENCE OF THE ORGANISATIONAL CULTURE SURVEY IN AUSTRALIA
}

\author{
RONEL ERWEE, \\ BERNADETTE LYNCH, \\ BRUCE MILLETT, \\ DON SMITH, \\ Faculty of Business \\ University of Southern Queensland, Australia \\ GERT ROODT \\ Department of Human Resource Management \\ Rand Afrikaans University
}

\begin{abstract}
The aim of this study is to assess whether the cross-cultural equivalence of the Organisational Culture Survey (OCS) persist in an Australian context. The nature of the instrument is presented which includes a clear statement of its South African origin and its place within a logical positivist paradigm. The sample consisted of 326 respondents from a population of managers of the Australian Institute of Management. This study confirms the instrument's validity and internal consistency within an Australian context, but that further research is required into the functional and conceptual equivalence of the survey items and dimensions underpinning the items to conclusively establish its utility. Finally, aspects of the 'organisational culture' construct underlying the survey need revision given recent trends in related systems, complexity and chaos theories.
\end{abstract}

\section{OPSOMMING}

Die doel van hierdie studie is om te bepaal of die kruis-kulturele ekwivalensie van die Organisational Culture Survey (OCS) in 'n Australiese konteks standhou. Die aard van die instrument word omskryf wat 'n duidelik standpunt rakende sy Suid-Afrikaanse oorsprong en sy plek in 'n logies-positivisitiese paradigma stel. Die steekproef het uit 326 respondente uit 'n populasie bestuurders van die Australiese Bestuursinstituut bestaan. Hierdie studie bevestig die instrument se geldigheid en interne konstantheid binne die Australiese konteks, maar ook dat verdere navorsing nodig is na die funksionele en konseptuele ekwivalensie van die items en die dimensies wat onderliggend daaraan is voordat die nutswaarde van die instrument ten volle bewys kan word. Ten slotte, moet aspekte van die konstruk 'organisasiekultuur' nader ondersoek word in die lig van verwikkelinge op die terrein van stelsel-, kompleksiteiten chaosteorieë.

\section{Organisational culture}

Organisational culture remains one of the most contested areas of academic inquiry within the broader field of organisational studies. It is characterised by competing definitions, epistomologies and research paradigms. While controversy exists about virtually all aspects of this construct including the mechanics and extent of its contribution to organisational performance, there is considerable consensus about the importance of organisational culture.

The Organisational Culture Survey (Van der Post, De Coning \& Smit, 1997) represents one line of inquiry within this field. Within this instrument organisational culture refers to:

'A system of shared meaning, the prevailing background fabric of prescriptions and proscriptions for behaviour, the system of beliefs and values and the technology and task of the organization together with the accepted approaches to these' (Van der Post et al., 1997, p. 148).

This definition of culture conforms to Green's (1989) notion of culture as the organisational equivalent of the individual's personality. Culture provides an underlying pattern to the behaviour of organisations, just as personality provides an underlying pattern to the behaviour of the individual.

Fundamental to the development of the OCS, is the belief that organisational culture can be defined in terms of a set of uniform dimensions or characteristics. This approach falls firmly within the classical positivist approach of culture that researchers have identified (Denison, 1996). Within this perspective the central aim is the development of a set of dimensions across which culture could be compared (Denison, 1996), and measured (Van der Post et al., 1997) and hence more effectively managed (Van der Post et al., 1998).
Generic challenges in cross-cultural research

The universal utility of such an instrument, particularly across cultures, must not be assumed however. It is no revelation that theory, research and indeed knowledge itself can be viewed as a cultural artifact. The uniqueness of knowledge to particular national groups is derived at least in part from the nature of national culture. A national culture can be regarded as a cluster of values, beliefs and assumptions acquired early in life by a group of people, that is unique to that group. (Beck \& Moore 1985; Hofstede 1991; Newman \& Nollen, 1996). Hofstede's cultural framework and comparative research on national cultures holds a pre-eminent position within this field of investigation and has provided a respected and substantive body of data both defining and measuring the differences be-tween national cultures (Chapman, 1997).

Differences in national culture complicate the processes of communication and research across borders. Chapman (1997) argued that words (and so questions) derive their meaning from their context. Differences in context lead to differences in meaning. This means that while a question can have a standard format use the same words in the same sequence - it cannot be assumed to have a single standard meaning. A respondent from one context will regard the question as having one meaning. A respondent from another context may give the same question a different meaning. A paradox emerges. Each respondent will respond to a different question, though ostensibly the same question has been asked of each. These issues of cross-cultural equivalence in scales were fully described by Berry and Lonner (1986) as well as Berry and Triandis (1980) who have identified functional, conceptual and metric equivalence.

Cross-cultural equivalence is not simply a matter of finding equivalent words. The experiences alluded to by the words, also need to be equivalent (Sekaran in Chapman, 1997). This means that while statements that refer to 'kangaroos' may be meaningful within an Australian context - kangaroos are 
unique to Australia - these statements will be less meaningful in other countries where kangaroos are unknown. An instrument has experiential/functional equivalence when respondents' inferences from a given statement are equivalent.

Instruments used cross-culturally may also require conceptual equivalence (Sekaran in Chapman, 1997). Concepts such as organisational culture or leadership may mean completely different things in different cultures or may even not exist in some cultures (Chapman, 1997). Poor conceptual equivalence in a study is characterised by the use of questions containing concepts that are consistently interpreted in one country with quite different interpretations offered in another country. The countries may even share a common language such as English and still lack conceptual equivalence.

The opportunities for miscommunication are potentially amplified when conducting cross-cultural research using survey instruments (Behling \& McFillen, 1997). This is a direct result of the limitations of the primary data gathering mechanism a one size fits all question and the narrow perspective quantitative data surveys provide. This may be characterised as a tradeoff between depth and breadth in cross-cultural survey research (Chapman, 1997).

\section{Challenges in cross-cultural research in business organisations} In addition to the generic challenges associated with cross-cultural research there are specific challenges associated with this type of research in the field of business. Differences between nations' cultures are associated with differences in the organisational culture, management theory and practices occurring at a local level. Literature emerging within the middle to late 1980's identified the impact of national culture on managerial behaviour (Sondergaard, 1994). It was at this point that the dominance of American management theory was challenged and the case made for unique management practices suited to unique national cultures. Indeed a substantive body of research supports the claim that specific management practices vary across cultures (Newman \& Nollen, 1996).

For example, currently a unique South African management philosophy is emerging that incorporates South African indigenous world-views as well as western management concepts (Christie, Lessem \& Mbigi, 1994). This has been stimulated most recently by the need for a uniquely South African management ethos and the rapid social and economic change South Africa is currently undergoing (Marais, 1996).

It could also be postulated that Australian management is similarly a reflection of Australias unique culture and circumstances. Bob Joss and Frank Blount are two high profile American CEOs headhunted for Australian corporations in the late 1980's. Blount, Joss and Mair (1999, p.264) refer to the suitably Australianised' variations of the American notions of management and leadership that were introduced during Blount's period as CEO of Telstra. Australian's approach to balancing work - recreation is another unique aspect of Australian business according to these authors. They suggest that Australians may have a better balance between work and recreation than their US colleagues. According to these authors Australians seem to work so that they can play. "(Australians)... realise that merely putting in long hours isn't what's important - it's the output you achieve not the input required' (Blount et al., 1999, pp. 202-3).

The extent of the differences between the South African and Australian national cultures and management practices remain something of an unknown. Some similarities in terms of national culture can however be postulated using Hofstede's (1991) framework and research findings. Both have low scores on power distance (Aus 36, RSA 49). Australia is more individualistic than South Africa (Aus 90, RSA 56). Both have similar masculinity (Aus 61; RSA 63) and uncertainty avoidance scores (Aus 51; RSA 49).
These perspectives about the embeddedness of research and business practices in national cultures must influence the career of instruments such as the Organisational Culture Survey outside its' culture of origin. In addition, the construct of culture underlying such instrument, is also in need to review.

Van der Post et al.s (1998) model of organisational culture is based on systems theory and they have used positivist research paradigms (Perry, Riege \& Brown, 1998) to construct and validate the surveys. Culture research falling within this perspective has been criticised by critical theorists such as Alvesson (1985, 1989, 1993) for its lack of political and ideological insight and its connection to the ideology of managerialism (Denison, 1996).

Culture research falling within this perspective can also be criticised for its implicit assumptions that organisations are relatively stable and predicable entities that operate on simple cause and effect, linear sequences. Within this framework the organisation is analysed into clearly identifiable component parts that can then be dealt with separately rather than holistically. Millett (1998) recommends that similar approaches to strategic planning and planned organisational change need to be re-appraised. Such approaches adopt what Collins refers to as inevitably flawed "n-step guides for change". Collins con-tinues, "we should not assume, therefore, that the various problems associated with 'defining' and 'diagnosing' change can be overcome by mechanistic methods which show no sympathy for the diverse drives, orientations, ambitions and yes, the fears of people." (Collins in Millett, 1998, p. 98).

Millett (1998) notes that if organisations are viewed as non-linear systems, it presents a problem for predicability. As a result and to its own detriment, mainstream organisational analysis is still focussed on linear cause-and-effect relationships with organisational performance and job satisfaction being key dependent variables (cf. Robbins, Millett, Cacioppe \& WatersMarsh, 1998). The OCS is most probably based on a model of organisational analysis that perceives culture as a feature of the organisation that can be studied and manipulated in isolation.

This study addresses the following research issue: "Do the metric properties of the OCS, designed and developed for South African applications, persist in an Australian context?"

\section{METHOD}

\section{The research participants}

The researchers approached the Australian Institute of Management (AIM) to participate in the research project. Permission was obtained from the AIM Council and the University of Southern Queensland (USQ) project was selected as one of the three projects that the Institute supported during 1999.

USQ negotiated the sampling frame to be 2000 members completing the OCS and another equal sample completing another survey out of a database of 4021 personal and company members in Queensland and the Northern Territory. This is a sample of convenience implying that the findings can only be generalised to the sample in question.

Previous AIM research indicated that low response $(8-10 \%)$ rates are common as members are 'over-surveyed'. In this project 326 questionnaires were returned that yielded a response rate of about $16 \%$.

Table 1 provides a brief overview of the biographical properties of the survey sample.

From Table 1 one can clearly infer that the majority of the respondents are male; are general managers from the senior management level; have a post-graduate qualification and are between 40 and 50 years old. 
TABLE 1

BIOGRAPHICAL PARTICULARS OF THE RESPONDENTS

\begin{tabular}{|c|c|c|}
\hline Category & Frequency & Percentage \\
\hline $\begin{array}{l}\text { Gender } \\
\text { Male } \\
\text { Female } \\
\text { Missing values } \\
\text { Total }\end{array}$ & $\begin{array}{r}248 \\
74 \\
4 \\
326\end{array}$ & $\begin{array}{r}76,1 \\
22,7 \\
1,2 \\
100\end{array}$ \\
\hline $\begin{array}{l}\text { Area of work } \\
\text { General manager } \\
\text { HR/Personnel } \\
\text { Training/education } \\
\text { Other } \\
\text { Missing values } \\
\text { Total }\end{array}$ & $\begin{array}{r}165 \\
29 \\
27 \\
99 \\
6 \\
326\end{array}$ & $\begin{array}{r}50,6 \\
8,9 \\
8,3 \\
30,4 \\
1,8 \\
100\end{array}$ \\
\hline $\begin{array}{l}\text { Management level } \\
\text { Supervisory managem. } \\
\text { Junior management } \\
\text { Middle management } \\
\text { Senior management } \\
\text { Missing values } \\
\text { Total }\end{array}$ & $\begin{array}{r}29 \\
15 \\
102 \\
173 \\
7 \\
326\end{array}$ & $\begin{array}{r}8,9 \\
4,6 \\
31,3 \\
53,1 \\
2,1 \\
100\end{array}$ \\
\hline $\begin{array}{l}\text { Highest academic Qua } \\
\text { Lower than } 12 \text { years } \\
12 \text { Years } \\
12 \text { Years and diploma } \\
\text { Undergrad degree } \\
\text { Post-grad degree } \\
\text { Missing values } \\
\text { Total }\end{array}$ & $\begin{array}{r}12 \\
18 \\
75 \\
94 \\
122 \\
5 \\
326\end{array}$ & $\begin{array}{r}3,7 \\
5,5 \\
23 \\
28,8 \\
37,4 \\
1,5 \\
100\end{array}$ \\
\hline $\begin{array}{l}\text { Age } \\
2130 \\
3140 \\
4150 \\
5160 \\
6170 \\
7185 \\
\text { Missing values } \\
\text { Total }\end{array}$ & $\begin{array}{r}16 \\
72 \\
132 \\
81 \\
18 \\
4 \\
3 \\
326\end{array}$ & $\begin{array}{r}5 \\
22,1 \\
40,2 \\
24,8 \\
5,5 \\
1,2 \\
0,9 \\
100\end{array}$ \\
\hline
\end{tabular}

The measuring instrument

Van der Post et al. (1997) proceed from the premise that organisational culture has a number of fundamental dimensions. They reviewed literature to identify organisational culture dimensions by various American researchers (eg. Likert, Litwin \& Stringer, Gordon, Gordon \& Cummings, Peters \& Waterman, Robbins, Rossiter, etc) and extracted one hundred and fourteen dimensions of organisational culture. A panel of South African human resource experts followed a two-step process to group the dimensions that overlap into logical categories, that resulted in fifteen dimensions of culture: Conflict resolution, Culture management, Customer orientation, Disposition towards change, Employee participation, Goal clarity, Human resource orientation, Identification with the organisation, Locus of authority, Management style, Organisation focus, Organisation integration, Performance orientation, Reward orientation, and Task orientation.

The preliminary questionnaire included a total of 169 items. An item analysis was conducted on the scores obtained from the questionnaire to select the best items and coefficient alpha was computed to determine the reliability of the instrument. Ninety-seven items $(57 \%)$ of the original number of items were retained to measure the 15 dimensions. The reliability coefficients for each of the culture dimensions varied between 0,788 and 0,932 (Van der Post et al., 1998, p. 33). The data relating to the retained 97 items were then factor analysed and factor loadings of between 0,8408 and 0,3916 on each of the factors were obtained, suggesting an acceptable level of construct validity. Van der Post et al. (1998, p.34) invited 128 South African industrial holding companies as a population to measure their organisational cultures and a total of $49(38.3 \%)$ companies participated. Out of the 49 companies a total number of 9471 persons were selected with an effective response return rate of $3617(38.2 \%)$. It was possible to obtain culture scores for the three organisational levels, management, supervisory and other for all 49 organisations.

\section{The research procedure}

The AIM managing director provided a letter of support to the project and the project was highlighted in an article in the AIM Newsletter that accompanied the mail-out.
The questionnaires were neatly printed in a book format and questions could be answered on a seven-point scale by simply circling/crossing the appropriate answer.

To maintain confidentiality of members' personal details, USQ prepared the surveys and AIM mailed the surveys to their members.

\section{Statistical analysis}

The factor analyses on item scores were conducted by the Statistical Consultation Service of the Rand Afrikaans University according to a procedure suggested by Schepers (1992). The iterative item analysis was conducted with the NP50 program of the National Institute for Personnel Research (NIPR).

\section{RESULTS}

First factor analysis on the item inter-correlation matrix The 97 items of the OCS were inter-correlated and rotated to a simple structure by means of the Varimax rotation. Owing to a lack of space, the inter-correlation matrix can not be reproduced here. Principal Axis Factoring was used as the extraction method.

Based on Kaiser's (1961) criterion (eigenvalues larger than unity), eleven factors were postulated. These eleven factors explained $73.55 \%$ of the variance in the factor space.

Subsequently, simplified factor scores (SFS) were calculated for these eleven factors. Meaningful item loadings were obtained on only eight of the eleven postulated factors.

Second factor analysis on the SFS inter-correlation matrix These eight SFS (obtained from the first factor analysis) were inter-correlated and the results of the inter-correlation of the SFS are displayed in Table 2.

TABLE 2

INTER-CORRELATION OF THE SIMPLIFIED FACTORS SCORES (SFS)

\begin{tabular}{lrrrrrrrr}
\hline & SFS1 & SFS 2 & SFS 3 & SFS 4 & SFS 5 & SFS 6 & SFS 7 & SFS 8 \\
\hline SFS 1 & 1,000 & & & & & & & \\
SFS 2 & $-0,9140$ & 1,000 & & & & & & \\
SFS 3 & 0,772 & $-0,779$ & 1,000 & & & & & \\
SFS 4 & 0,812 & $-0,842$ & 0,673 & 1,000 & & & & \\
SFS 5 & 0,796 & $-0,755$ & 0,612 & 0,685 & 1,000 & & & \\
SFS 6 & $-0,730$ & 0,681 & $-0,545$ & $-0,588$ & $-0,578$ & 1,000 & & \\
SFS 7 & $-0,470$ & 0,377 & $-0,333$ & $-0,312$ & $-0,396$ & 0,476 & 1,000 & \\
SFS 8 & 0,822 & $-0,759$ & 0,684 & 0,669 & 0,703 & $-0,586$ & $-0,361$ & 1,000
\end{tabular}

According the Kaiser's (1961) criterion a single factor was postulated. Table 3 provides the eigenvalues of the unreduced factor matrix. This factor explained $69.25 \%$ of the variance in the factor space.

TABLE 3

EIGENVALUES OF THE UNREDUCED INTER-CORRELATION MATRIX

\begin{tabular}{ll}
\hline ROOT & EIGENVALUES \\
\hline $\mathbf{1}$ & $\mathbf{5 , 5 4 1}$ \\
2 & 0,840 \\
3 & 0,429 \\
4 & 0,386 \\
5 & 0,339 \\
6 & 0,261 \\
7 & 0,134 \\
8 & $\underline{0,067}$ \\
Trace & 8,000 \\
\hline
\end{tabular}

The factor solution converged after five iterations. Table 4 provides the rotated factor matrix of the OCS.

An iterative item analysis procedure was conducted on this single factor and a very high Cronbach Alpha coefficient of 0,991 was obtained. Only two items were omitted after the fourth (item 21) and the tenth (item 79) iteration without any effect on the reliability coefficient. Table 5 provides the item statistics for the OCS after the fourth iteration. 
TABLE 4

FACTOR MATRIX OF THE OCS

\begin{tabular}{|c|c|c|c|c|}
\hline SFS & Items & $\mathbf{N}$ & Factor I & $\mathbf{h j}^{2}$ \\
\hline SFS1 & $\begin{array}{l}7, \mathbf{8}, 10, \mathbf{1 1}, \mathbf{1 5}, 18,23,24,26,27, \mathbf{2 8}, 29,30 \\
31, \mathbf{3 2}, \mathbf{3 3}, 36,38, \mathbf{4 1}, 43,44,46, \mathbf{5 0}, 51, \mathbf{5 4} \\
\mathbf{5 6}, \mathbf{5 7}, \mathbf{6 2}, \mathbf{6 5}, 66, \mathbf{6 8}, \mathbf{6 9}, \mathbf{7 0}, 71, \mathbf{7 2}, \mathbf{7 3}, \mathbf{7 5} \\
\mathbf{7 8}, 80, \mathbf{8 1}, 82,84,87, \mathbf{8 8}, 90, \mathbf{9 2}, 93, \mathbf{9 5}\end{array}$ & 49 & 0,983 & 0,966 \\
\hline SFS2 & $\begin{array}{l}2,9,12,14,16,35,39,40,42,48,49,58,59 \\
60,64,67,77,74,76,89,97\end{array}$ & 21 & $-0,944$ & 0,891 \\
\hline SFS3 & $5,19,22,37,47,53,63$ & 7 & 0,791 & 0,626 \\
\hline SFS4 & $\mathbf{1}, 25, \mathbf{4 5}, 83, \mathbf{8 5}, 91$ & 6 & 0,833 & 0,695 \\
\hline SFS5 & $6,96,86$ & 3 & 0,811 & 0,658 \\
\hline SFS6 & $3,4,17,52$ & 4 & $-0,730$ & 0,533 \\
\hline SFS7 & $13,20,21,61,79,94$ & 6 & $-0,457$ & 0,209 \\
\hline SFS8 & 34 & $\frac{1}{97}$ & 0,827 & 0,684 \\
\hline
\end{tabular}

bold items were reflected

variance explained in factor space $=69,25 \%$

Cronbach Alpha $=0,991$

TABLE 5

ITEM STATISTICS FOR THE OCS $(\mathrm{N}=326)$

\begin{tabular}{|c|c|c|c|c|c|}
\hline Item & Item mean & Item SD & Skewness & $\begin{array}{l}\text { Reliability } \\
\text { Index }\end{array}$ & $\begin{array}{l}\text { Item-test } \\
\text { Correlation }\end{array}$ \\
\hline A1 & 4,767 & 1,961 & 0,382 & 1,067 & 0,544 \\
\hline A2 & 5,653 & 1,697 & 1,271 & 1,113 & 0,656 \\
\hline A3 & 4,120 & 2,121 & 0,105 & 1,249 & 0,589 \\
\hline A4 & 4,252 & 2,062 & 0,218 & 1,341 & 0,650 \\
\hline A 5 & 4,847 & 1,835 & $-0,705$ & 1,167 & 0,636 \\
\hline A6 & 5,113 & 1,593 & $-0,904$ & 0,871 & 0,547 \\
\hline A7 & 4,902 & 1,900 & $-0,649$ & 1,460 & 0,769 \\
\hline A8 & 5,138 & 1,870 & 0,793 & 1,392 & 0,744 \\
\hline A9 & 5,285 & 1,919 & 0,845 & 1,487 & 0,775 \\
\hline A10 & 4,887 & 1,790 & $-0,731$ & 1,161 & 0,649 \\
\hline A11 & 4,966 & 1,994 & 0,637 & 1,629 & 0,817 \\
\hline A12 & 4,672 & 2,043 & 0,356 & 1,568 & 0,768 \\
\hline A13 & 4,500 & 1,950 & 0,299 & 1,103 & 0,566 \\
\hline A14 & 4,025 & 1,764 & 0,084 & 0,681 & 0,386 \\
\hline A15 & 4,699 & 1,969 & 0,478 & 1,461 & 0,742 \\
\hline A16 & 5,248 & 1,859 & 0,896 & 1,345 & 0,724 \\
\hline A17 & 4,193 & 1,990 & 0,126 & 1,343 & 0,675 \\
\hline A18 & 4,503 & 1,821 & $-0,491$ & 1,287 & 0,707 \\
\hline A19 & 5,653 & 1,517 & $-1,362$ & 0,972 & 0,641 \\
\hline A20 & 3,206 & 1,903 & $-0,626$ & 0,599 & 0,315 \\
\hline$\star \mathrm{A} 21$ & 2,779 & 1,688 & $-1,077$ & 0,348 & 0,206 \\
\hline A22 & 5,702 & 1,464 & $-1,417$ & 1,003 & 0,686 \\
\hline A23 & 4,905 & 1,699 & $-0,707$ & 1,085 & 0,639 \\
\hline A24 & 4,420 & 1,886 & $-0,320$ & 1,456 & 0,772 \\
\hline A25 & 4,868 & 1,788 & $-0,651$ & 1,285 & 0,719 \\
\hline A26 & 4,617 & 1,732 & $-0,528$ & 1,321 & 0,763 \\
\hline A27 & 4,248 & 1,911 & $-0,343$ & 1,434 & 0,750 \\
\hline A28 & 5,052 & 2,003 & 0,698 & 1,648 & 0,822 \\
\hline A29 & 4,552 & 1,842 & $-0,424$ & 1,465 & 0,795 \\
\hline A30 & 4,739 & 1,862 & $-0,533$ & 1,494 & 0,902 \\
\hline A31 & 4,184 & 1,909 & $-0,209$ & 1,456 & 0,762 \\
\hline A32 & 4,730 & 1,969 & 0,432 & 1,520 & 0,772 \\
\hline A33 & 5,089 & 1,888 & 0,700 & 1,486 & 0,787 \\
\hline A34 & 5,037 & 1,797 & $-0,702$ & 1,480 & 0,823 \\
\hline A 35 & 4,825 & 1,844 & 0,488 & 1,493 & 0,810 \\
\hline A36 & 4,715 & 1,899 & $-0,567$ & 1,692 & 0,891 \\
\hline A 37 & 5,840 & 1,607 & 1,509 & 1,078 & 0,671 \\
\hline A 38 & 4,387 & 1,976 & $-0,326$ & 1,591 & 0,805 \\
\hline A39 & 5,006 & 1,945 & 0,682 & 1,578 & 0,811 \\
\hline A 40 & 5,291 & 1,852 & 0,956 & 1,394 & 0,753 \\
\hline A 41 & 4,920 & 1,956 & 0,562 & 1,709 & 0,874 \\
\hline A42 & 5,218 & 1,727 & 0,845 & 1,389 & 0,804 \\
\hline A 43 & 4,748 & 1,869 & $-0,578$ & 1,578 & 0,845 \\
\hline A44 & 4,837 & 1,787 & $-0,651$ & 1,449 & 0,811 \\
\hline A 45 & 4,684 & 1,969 & 0,473 & 1,513 & 0,768 \\
\hline A46 & 4,837 & 1,888 & $-0,545$ & 1,527 & 0,809 \\
\hline A47 & 5,454 & 1,681 & $-1,137$ & 1,122 & 0,667 \\
\hline A48 & 5,374 & 1,747 & 1,097 & 1,079 & 0,617 \\
\hline A49 & 5,236 & 1,769 & 0,879 & 1,175 & 0,664 \\
\hline A50 & 4,755 & 1,907 & 0,526 & 1,448 & 0,759 \\
\hline A51 & 5,034 & 1,837 & $-0,919$ & 1,484 & 0,808 \\
\hline A52 & 3,831 & 1,940 & $-0,146$ & 1,164 & 0,600 \\
\hline A53 & 5,693 & 1,592 & $-1,340$ & 1,121 & 0,704 \\
\hline A54 & 4,567 & 1,831 & $-0,340$ & 1,505 & 0,822 \\
\hline A55 & 4,264 & 1,954 & $-0,230$ & 1,488 & 0,762 \\
\hline A56 & 4,512 & 2,026 & 0,337 & 1,647 & 0,813 \\
\hline A 57 & 5,184 & 1,905 & 0,803 & 1,693 & 0,889 \\
\hline A58 & 5,368 & 1,764 & 1,032 & 1,387 & 0,786 \\
\hline A59 & 5,414 & 1,661 & $-0,581$ & 1,244 & 0,749 \\
\hline A60 & 4,709 & 1,843 & 0,526 & 1,008 & 0,547 \\
\hline A61 & 3,304 & 1,875 & 0,455 & 0,860 & 0,458 \\
\hline A62 & 4,604 & 1,853 & $-0,500$ & 1,338 & 0,722 \\
\hline A63 & 4,718 & 1,647 & 0,000 & 0,915 & 0,555 \\
\hline A64 & 4,776 & 1,875 & 0,554 & 1,526 & 0,814 \\
\hline A65 & 4,856 & 1,751 & $-0,778$ & 1,264 & 0,722 \\
\hline A66 & 5,117 & 1,745 & $-0,900$ & 1,442 & 0,826 \\
\hline A67 & 5,110 & 1,994 & 0,758 & 1,572 & 0,788 \\
\hline A68 & 5,187 & 1,915 & 0,788 & 1,563 & 0,816 \\
\hline
\end{tabular}

\begin{tabular}{|c|c|c|c|c|c|}
\hline Item & Item mean & Item SD & Skewness & $\begin{array}{c}\text { Reliability } \\
\text { Index }\end{array}$ & $\begin{array}{l}\text { Item-test } \\
\text { Correlation }\end{array}$ \\
\hline A69 & 4,761 & 1,965 & 0,485 & 1,658 & 0,844 \\
\hline A70 & 5,150 & 1,924 & 0,736 & 1,705 & 0,886 \\
\hline A71 & 4,810 & 1,675 & $-0,666$ & 1,224 & 0,731 \\
\hline A72 & 5,181 & 1,793 & $-0,784$ & 1,545 & 0,862 \\
\hline A73 & 5,120 & 1,715 & $-0,761$ & 1,420 & 0,828 \\
\hline A74 & 4,831 & 1,671 & $-0,612$ & 0,793 & 0,474 \\
\hline A75 & 4,414 & 2,101 & 0,269 & 1,649 & 0,785 \\
\hline A76 & 4,804 & 1,667 & $-0,632$ & 1,102 & 0,661 \\
\hline A77 & 4,951 & 1,816 & 0,594 & 1,479 & 0,815 \\
\hline A78 & 4,905 & 2,000 & 0,621 & 1,616 & 0,808 \\
\hline$\star A 79$ & 3,037 & 1,757 & $-0,813$ & 0,486 & 0,277 \\
\hline A80 & 4,021 & 2,064 & $-0,073$ & 1,649 & 0,799 \\
\hline A81 & 5,006 & 1,949 & 0,704 & 1,552 & 0,797 \\
\hline A 82 & 4,515 & 1,962 & $-0,368$ & 1,731 & 0,882 \\
\hline A 83 & 4,862 & 1,793 & $-0,661$ & 1,461 & 0,815 \\
\hline A84 & 4,525 & 1,981 & $-0,454$ & 1,724 & 0,870 \\
\hline A 85 & 4,926 & 1,917 & 0,636 & 1,360 & 0,709 \\
\hline A 86 & 4,877 & 1,832 & $-0,660$ & 1,416 & 0,773 \\
\hline A 87 & 4,779 & 1,791 & $-0,648$ & 1,471 & 0,821 \\
\hline A88 & 5,120 & 1,724 & 0,768 & 1,282 & 0,743 \\
\hline A89 & 4,822 & 1,951 & $-0,641$ & 1,638 & 0,839 \\
\hline A90 & 4,954 & 1,767 & $-0,789$ & 1,498 & 0,848 \\
\hline A91 & 4,966 & 1,753 & $-0,766$ & 1,446 & 0,825 \\
\hline A92 & 5,252 & 1,743 & 0,882 & 1,383 & 0,794 \\
\hline A93 & 4,353 & 1,915 & $-0,287$ & 1,552 & 0,810 \\
\hline A94 & 4,629 & 1,779 & 0,426 & 0,658 & 0,370 \\
\hline A95 & 5,104 & 1,796 & 0,734 & 1,371 & 0,764 \\
\hline A96 & 5,037 & 1,688 & $-0,831$ & 1,334 & 0,790 \\
\hline A97 & 4,160 & 2,080 & $-0,140$ & 1,659 & $0,798 \mathrm{z}$ \\
\hline
\end{tabular}

* - Items removed after the item analysis

It is clear from Table 5 that the item reliabilities according to the Gulliksen (1950) index vary between 0,599 and 1,731 with only ten items having values lower than one. The item-test total correlations vary between 0,315 and 0,891 with only seven items below 0,50 that contributes to the extremely high internal consistency of the scale. The item skewness coefficients vary between 1,509 (highly positive) and minus 1,417 (highly negative).

TABLE 6

QUALITATIVE ANALYSIS OF SUB-FACTOR 1 IN AUSTRALIA

\begin{tabular}{|c|c|c|}
\hline Items & South African Dimension Title & $\begin{array}{l}\text { Percentage of items } \\
\text { from the original } \\
\text { dimension }\end{array}$ \\
\hline $\begin{array}{l}93, \mathbf{6 9}, \mathbf{5 6}, \mathbf{1 5}, \\
82, \mathbf{3 2}, 24,\end{array}$ & $\begin{array}{l}\text { Conflict Resolution-The degree to which the } \\
\text { organisation is perceived to encourage em- } \\
\text { ployees to air conflicts and criticisms openly }\end{array}$ & $100 \%$ \\
\hline $\begin{array}{l}66,43,41,68 \\
70\end{array}$ & $\begin{array}{l}\text { Disposition towards change - The degree to } \\
\text { which employees are encouraged to be creative } \\
\text { and innovative and to constantly search for be- } \\
\text { tter ways of getting the job done }\end{array}$ & $100 \%$ \\
\hline $\begin{array}{l}28,7,11,57 \\
72\end{array}$ & $\begin{array}{l}\text { Human Resource Orientation-The extent } \\
\text { to which the organisation is perceived as hav- } \\
\text { ing a high regard for its human resources }\end{array}$ & $100 \%$ \\
\hline $\begin{array}{l}31,27, \mathbf{5 0}, 65 \\
87, \mathbf{6 2}, 84\end{array}$ & $\begin{array}{l}\text { Employee participation - The extent to which } \\
\text { the employees perceive themselves as participating } \\
\text { in the decision-making of the organisation }\end{array}$ & $100 \%$ \\
\hline $\begin{array}{l}75, \quad 81,80, \quad 18 \\
51,36,\end{array}$ & $\begin{array}{l}\text { Management Style }- \text { The degree to which } \\
\text { managers provide clear communication, assis- } \\
\text { tance and support to their subordinates }\end{array}$ & $100 \%$ \\
\hline $\begin{array}{l}30,54, \quad 8, \quad 46, \\
\mathbf{3 3},\end{array}$ & $\begin{array}{l}\text { Organisation integration }- \text { The degree to } \\
\text { which various subunits within the organisation } \\
\text { are actively encouraged to operate in a co-ordi- } \\
\text { nated way by co-operating effectively towards the } \\
\text { achievement of overall organisational objectives }\end{array}$ & $83 \%$ \\
\hline $88,78,92,26$ & $\begin{array}{l}\text { Identification with the organisation - The } \\
\text { degree to which the employees are encouraged } \\
\text { to identify with the organisation. }\end{array}$ & $57 \%$ \\
\hline $10, \mathbf{9 5}, 90$ & $\begin{array}{l}\text { Locus of authority - the degree of authority, } \\
\text { freedom and independence that individuals ha- } \\
\text { ve in their jobs }\end{array}$ & $50 \%$ \\
\hline $29,71,38$ & $\begin{array}{l}\text { Reward orientation - The degree to which } \\
\text { reward allocations are based on employee per- } \\
\text { formance in contrast to seniority, favouritism } \\
\text { or any other non-performance criterion }\end{array}$ & $29 \%$ \\
\hline 44 , & $\begin{array}{l}\text { Culture management - The extent to which } \\
\text { the organisation actively and deliberately enga- } \\
\text { ges in shaping the organisation's culture }\end{array}$ & $17 \%$ \\
\hline 73 , & $\begin{array}{l}\text { Performance orientation - The extent to } \\
\text { which emphasis is placed on individual } \\
\text { accountability for clearly defined results and a } \\
\text { high level of performance }\end{array}$ & $14 \%$ \\
\hline 23 , & $\begin{array}{l}\text { Task structure - The degree to which rules } \\
\text { and regulations and direct supervision are ap- } \\
\text { plied to manage employee behaviour }\end{array}$ & $11 \%$ \\
\hline
\end{tabular}


The first two factors obtained in the first factor analysis of the Australian survey (SFS1 49 items, SFS2 21 items - see Table 4) were negatively correlated (see Table 2 ). The content of the first three Australian sub-factors was qualitatively analysed by the research team to ascertain whether the Australian sample interpreted corporate culture differently from the RSA sample. The Van der Post et al. $(1997,1998)$ study yielded 15 separate dimensions of organisational culture.

TABLE 7

QUALITATIVE ANALYSIS OF SUB-FACTOR 2 IN AUSTRALIA

\begin{tabular}{|c|c|c|}
\hline Items & South African Dimension Title & $\begin{array}{l}\text { Percentage of items } \\
\text { from the original } \\
\text { dimension }\end{array}$ \\
\hline $\begin{array}{l}77,89,58,14,67, \\
49,39\end{array}$ & $\begin{array}{l}\text { Organisation focus - The extent to which } \\
\text { the organisation is perceived to be concen- } \\
\text { trating on those activities which form part of } \\
\text { the fundamentals of the business }\end{array}$ & $100 \%$ \\
\hline $\begin{array}{l}2,59,76,48,9 \\
16,\end{array}$ & $\begin{array}{l}\text { Performance orientation - The extent to } \\
\text { which emphasis is placed on individual } \\
\text { accountability for clearly defined results and a } \\
\text { high level of performance }\end{array}$ & $86 \%$ \\
\hline $40,74,64$, & $\begin{array}{l}\text { Culture management - The extent to which } \\
\text { the organisation actively and deliberately enga- } \\
\text { ges in shaping the organisation's culture }\end{array}$ & $50 \%$ \\
\hline $12,60,97$ & $\begin{array}{l}\text { Reward orientation - The degree to which } \\
\text { reward allocations are based on employee per- } \\
\text { formance in contrast to seniority, favouritism } \\
\text { or any other non-performance criterion }\end{array}$ & $43 \%$ \\
\hline 35,42 & $\begin{array}{l}\text { Goal clarity - The degree to which the } \\
\text { organisation creates clear objectives and perfor- } \\
\text { mance expectations }\end{array}$ & $29 \%$ \\
\hline
\end{tabular}

Bold items are reflected

The first Australian sub-factor (see Table 6; and SFS1 in Table 4) grouped all the items from the following dimensions identified in the South African study: conflict resolution, disposition to change, employee participation, human resource orientation, and management style. It also included some items from the following dimensions; organisation integration, (83\% of items) identification with the organisation ( $57 \%$ of items), locus of authority $(50 \%$ of items), reward orientation ( $29 \%$ of items), culture management $(17 \%$ of items), performance orientation (14\% of items), task structure (11\% of items).

TABLE 8

QUALITATIVE ANALYSIS OF SUB-FACTOR 3 IN AUSTRALIA

\begin{tabular}{lll}
\hline Items & South African Dimension Title & $\begin{array}{l}\text { Percentage of items } \\
\text { from the original } \\
\text { dimension }\end{array}$ \\
\hline $\mathbf{2 2}, \quad 37, \quad \mathbf{4 7}, \quad \mathbf{5 3}, \begin{array}{l}\text { Customer orientation - the extent to which } \\
\text { the organisation takes the views of customers } \\
\text { seriously and actively responds to such views }\end{array}$ \\
$\begin{array}{l}\text { Goal clarity - The degree to which the orga- } \\
\text { nisation creates clear objectives and perfor- } \\
\text { mance expectations }\end{array}$ \\
$\begin{array}{l}\text { Reward orientation - The degree to which } \\
\text { reward allocations are based on employee per- } \\
\text { formance in contrast to seniority, favouritism } \\
\text { or any other non-performance criterion }\end{array}$ \\
\hline
\end{tabular}

Bold items are reflected

The second sub-factor (see table 7; and SFS2 - Table 4) in the Australian sample, (that correlated negatively with the first sub-factor), included all the items from organisation focus and some items from the following dimensions: performance orientation $(86 \%$ of items), culture management $(50 \%$ of items), reward orientation ( $43 \%$ of items), goal clarity $(29 \%$ of items)

The third sub-factor (see Table 8, SFS3 - see Table 4) grouped all items in the customer orientation dimension and some items from goal clarity (14\% of items) and reward orientation (14\% of items) dimensions. This factor is positively correlated with sub-factor 1 but negatively correlated with sub-factor 2 (see Table 2).

\section{DISCUSSION}

It is clear from the factor analyses and the item analysis that the construction of the OCS is based on sound psychometric principles. Although the current procedure of factor analysis differs from the procedure that was used in the construction of the questionnaire originally (Van der Post et al., 1997; 1998), the questionnaire still yielded excellent results. The factor analyses resulted in a robust single factor that indicates a sound theoretical basis as well as a sound procedure in the construction of the OCS. This assumption is further support-ed by an extremely high internal consistency of 0,991 . This indicates a very high level of reliability and only a limited amount of error variance in the measurement of the construct "organisational culture". One can therefore conclude that the OCS shows a high level of metric equivalence between the South African and the Australian contexts.

The results obtained from the factor analyses and the item analysis further indicates that the OCS is portable between the South African culture and the Australian culture. This is probably ascribable to the fact that both countries have common features associated with a predominantly Western business culture, also referred to as functional equivalence.

It should be noted however, that findings could not be interpreted in terms of the original 15 South African dimensions, owing to the different procedure used for the factor analyses. The conceptual equivalence of the OCS could therefore not be evaluated. It seems that "organisational culture", as a construct is applicable and measurable with this instrument in Australia, but the exact nature of its constitution still needs further investigation. It can therefore be concluded that the OCS appears to show a high degree of cross-cultural equivalence in the Australian context.

It is clear from the above literature review that simplistic models of organisational effectiveness, (where for instance only bivariate analyses; or only simple linear models of cause and effect; or even only a single criterion of effectiveness is used), have to be seriously reconsidered from a research, theoretical as well as a practical perspective. A more complex model of organisations, that portrays them as being constructed from different systems or subsystems, which interact on different levels, is perhaps a bit closer to reality.

Therefore, future research issues that need to be addressed, must focus on the following:

- emerging models of organisational culture based on related systems, chaos and complexity theories;

- .01w sthe implications of these new models for organisational culture research and related assessment methodologies; as well as

- how existing measuring instruments and research methodologies for organisational culture should be adapted.

These issues have not been fully addressed yet. Academics and researchers will be confronted with emerging paradigms and will be challenged to adapt existing course materials, learning and research strategies to reflect these insights.

\section{REFERENCES}

Alvesson, M. (1985). A critical framework for organizational analysis. Organizational Studies. 6, 117-138.

Alvesson, M. (1989). The culture perspective on organizations: Instrumental values and basic features of culture. Scandinavian Journal of Management, 5(2), 123-136.

Alvesson, M. (1993). Cultural perspectives on organizations. Cambridge; England Cambridge University Press.

Beck, B., \& Moore, L. (1985). Linking the host culture to orga- 
nizational variables. In P. J. Frost et al Organizational culture, 335-54, Beverley Hills, California: Sage.

Behling, O. \& McFillen, J.M. (1997). Translating questionnaires: personal experiences and general conclusions. Proceedings of the 14 th Pan Pacific Conference, Kuala Lumpur Malaysia, 3-5 June, pp. 10-12.

Berry, J.W. \& Lonner W.J. (eds.) (1986). Field methods in cross-cultural research. Beverley Hills, CA.: Sage.

Berry, J.W. \& Triandis, H.C. (eds.) (1980). Handbook of cross-cultural psychology. (Vol. 2), Boston: Allyn \& Bacon.

Blount, F., Joss, B., \& Mair, D. (1999). Managing in Australia. Sydney: Lansdowne.

Chapman, M. (1997). Social anthropology, business studies and cultural issues. International Studies of Management and Organisation, Winter, 26(4), 3-30.

Christie, P., Lessem, R. \& Mbigi, L. (1994). African Management - Philosophies, Concepts and Applications. Johannesburg: Knowledge Resources.

Denison, D. (1996). What's the difference between organizational culture and organizational climate? A native's point of view on a decade of paradigm wars. Academy of Management Review. Jul 1996; 21(3), 619-654.

Green, L. (1989). Corporate culture asset or liability. Human resource management Yearbook, pp. 72-74.

Gulliksen, H. (1950). Theory of mental tests. New York: John Wiley.

Hofstede, G. (1991). Cultures and Organisations: software of the mind. London, McGraw-Hill.

Kaiser, H.F. (1961). A note on Guttman's lower bound for the number of common factors. British Journal of Statistical Ps $\gamma$ chology, 14(1), 1 .
Marais C (1996). A Paradigm Shift About Diversity in Two South African Companies. Unpublished MBA thesis, University of Pretoria Graduate School of Management.

Millett, B. (1998) Understanding Organisations: The Dominance of Systems Theory. Working paper, Department of Human Resource Management, University of Southern Queensland

Newman, K.L. \& Nollen, S. D. (1996). Culture and congruence: The fit between management practices and national culture. Journal of International Business Studies, 1996, 27(4), p. 27, p. 753.

Perry, C., Riege, A. \& Brown, L. (1998). Realism Rules OK : Scientific Paradigms in Marketing Research about Networks. Paper submitted to the ANZMAC conference December 1998.

Robbins, S.P., Millett, B., Cacioppe, R. \& Waters-Marsh, T. (1998). Organisational Behaviour: Leading and managing in Australia and New Zealand. Sydney: Prentice-Hall.

Schepers, J.M. (1992). Toetskonstruksie: Teorie en Praktyk. Johannesburg: Rand Afrikaans University publishers.

Sondergaard, M. (1994). Research note; Hofstede's consequences a study of reviews, citations and replications. (Special Issue on Cross-National Organizational Culture) Organizational Studies, Summer, 15(3), 447 (10)

Van der Post, W.Z., De Coning T.J., \& Smit, E. vd M. (1997). An instrument to measure organisational culture. South African Journal of Business Management, 28(4), 147-168.

Van der Post, W.Z., De Coning T.J., \& Smit, E. vd M. (1998). The relationship between organisational culture and financial performance: some South African evidence. South African Journal of Business Management, 29(1), 30-40. 